\title{
Guest Editor's Introduction: Understanding Creationism in Korea
}

Hyung Wook Park*

Creationism is a system of belief in god's creation of the world, including humans and other living organisms. Many religions of the world have their own versions of creationism. Yet historians have tracked down the historical origin of its modern form, associated with a resolute denial of evolutionism, in early twentieth century American Christian fundamentalism. Experiencing the threats of the First World War, labor unrest, communism, and higher criticism in theology, many American Protestants found their enemy in the lack of real Christian faith, for which Darwinism was primarily responsible. To them, Charles Darwin (1809-1882) claimed that the world was just a product of chance, and that humans came from monkeys. They thus tried to remove evolution from school textbooks by revising state laws on education. An early and highly notorious case of this attempt was the Scopes Trial of 1925, in which John T. Scopes, a high school teacher, was tried in court for teaching evolution in a Tennessee public school. ${ }^{1}$ As the historian of science Ronald L. Numbers has shown, however, American fundamentalists in the 1920s did not com-

* Assistant Professor, History Programme, Nanyang Technological University, Singapore.

1 For an excellent historical analysis of the Scopes Trial, see Edward J. Larson, Summer for the Gods: The Scopes Trial and America's Continuing Debate over Science and Religion (New York: Basic Books, 2006). 
pletely reject evolution. ${ }^{2}$ Even William Jennings Bryan (1860-1925), a prosecution attorney in the trial, did not say that the Biblical account of the world's creation in six days was literally true. Perhaps God's creation took place over a long period of time, which might be even millions of years, which Darwin thought was necessary for evolution to unfold.

A more problematic version of creationism appeared in the 1960 s by the American hydraulic engineer Henry M. Morris (1918-2006) and fundamentalist theologian John C. Whitcomb. In their monograph, Genesis Flood (1961), they appropriated the Canadian Seventh-day Adventist George McCready Price's (1870-1963) argument that the records in Scripture were literally true and accurately reflected in the current forms of geological strata and fossilized animals. A meticulous scientific investigation would thus reveal the truth of the Bible, in which the Genesis Flood was particularly important as a decisive catastrophe that supposedly shaped the forms of the earth's surface. More significantly, Morris and Whitcomb believed in the six-day creation of the world described in the Bible as well as the six-thousand-year history of the world, proposed by James Ussher (1581-1656) based on his thorough scrutiny of the Biblical figures' lifespan. Ironically, this young-earth creed-which might sound the least scientific to most professional geologists and biologists-was called "scientific creationism" or "creation science" because of its advocates' strategy to change school textbooks. As the law did not allow the teaching of religion in public schools, their religious theory had to be a "science."

The theory of Morris and Whitcomb was never seriously considered a science in mainstream academic communities, but it was surprisingly successful in persuading not just American Christian fundamentalists but also those in other countries with different religious traditions, including Catholics, Jews, Hindus, and Muslims in Asia, Africa, and Europe. As has been described in two edited volumes, The Cultures of Creationism

2 Ronald L. Numbers, The Creationists: From Scientific Creationism to Intelligent Design (Cambridge: Harvard University Press, 2006), 33-50; 69-87. 
(2004) and Creationism in Europe (2014), creationism spread across national, political, and religious boundaries. ${ }^{3}$ Of course, this cross-cultural expansion does not mean that these non-Protestant and non-American creationists simply "accepted" the American religious theory. They appropriated creationism in their own theological and cultural circumstances, and some of them synthesized new versions by selectively combining the American and their own creationist notions. Through this process of appropriation, creationism has now become a global issue that demands a serious scholarly approach. As Peter Berger has argued, it does not seem that the world is becoming more secular over time. ${ }^{4}$ It is probably undergoing a form of "desecularization," in which the spread of creationism appears to be an important part.

The Koreans' reception of creationism must be understood in this context. Henry Morris's young-earth creationism found its place in South Korea during the 1980 World Evangelical Crusade (WEC) in Seoul, organized by the Reverend Kim Joon Gon (Kim Chun'gon, 1925-2009), the renowned anticommunist pastor and founder of the Campus Crusade for Christ in Korea. At the time, Morris and other American young-earth creationists came to Korea to hold a two-day seminar as an event in WEC, which - according to Kim-attracted more than three hundred scholars across the country. ${ }^{5}$ In the next year, scientific professionals gathered at the WEC established the Korean Association for Creation Research (KACR, Han'guk Ch'angjo Kwahakhoe), which became the institutional

3 Simon Coleman and Leslie Carlin, eds., Cultures of Creationism: AntiEvolutionism in English-Speaking Countries (Aldershot: Ashgate, 2004); Stefaan Blancke, Hans Henrik Hjermitslev, and Peter C. Kjærgaard, eds., Creationism in Europe (Baltimore: Johns Hopkins University Press, 2014).

4 Peter L. Berger, ed., The Desecularization of the World: Resurgent Religion and World Politics (Grand Rapids: William B. Eerdmans, 1999).

5 Kim Joon Gon, “Ch'angjo Kwahakhoe 20nyŏnŭl Chik'yŏbomyŏ (Looking at the Twenty Years of the KACR)," in Han'guk Ch'angjo Kwahakhoe Isip Nyŏn Sa (Twenty-year History of the Korean Association for Creation Research) (Seoul: KACR, 2001), 53. 
center of young-earth creationism. They then began to use the term "ch'angjo kwahak" as the direct translation of the English term "creation science" or "scientific creationism."

The year of 1980 was different from any previous years in the history of creationism in Korea, when Koreans encountered creationism in other forms. Indeed, after the Scopes Trial, The Christian Messenger (Kidok Shinbo) published two articles on creation and evolution. ${ }^{6}$ William Bell Dawson's The Bible Confirmed by Science (1932) also came out in the Korean language in 1936. However, these publications did not completely reject Darwin. Their main theoretical standpoints were either theistic evolutionism or progressive creationism, which tentatively incorporated some portions of Darwin's theory, including his supposition of gradual changes over extended periods of time. In contrast, the Reverend Pak Hyŏngnyong (1897-1978) introduced young-earth creationism to Korea through his 1932 translation of George McCready Price's paper, "Modern Science Discredits Evolution."7 The Seventh-day Adventist Church in Korea also published several Korean-language papers vindicating Price's theory. ${ }^{8}$ But these publications had little impact on Korean Christians, just as Price's theory remained a minor doctrine in North America itself. After liberation in 1945, creationism was barely mentioned in any of the Kore-

6 For the Korean creationism during the Japanese Colonial Rule, see Choi Taeyon, "Sin Kwa Chinhwa: Han'guk Ǔi Yusin Chinhwaron Nonjaeng (God and Evolution: Korean Debates on Theistic Evolution)," Sinanggwa Hangmun 9 (June 2004): 267-93; Hyung Wook Park and Kyuhoon Cho, "Science, State, and Spirituality: Stories of Four Creationists in South Korea," History of Science 56 (March 2018): 42-6. Also see Sung-Deuk Oak's blog. https://m.blog.naver.com/1000oaks/ 221300101971

7 George McCready Price, “Hyŏn'gwahak Ǔn Chinhwaron Ǔl Ǔimun Handa (Modern Science Discredits Evolution)," trans. by Pak Hyŏngnyong, Sinhak Chinam 14 (November 1932): 35-40. Price inspired Morris's later theory, but differed from him in believing that the universe itself was very old, in contrast to the young earth theory. See Numbers, The Creationists, 154-6.

8 See, for example, I. E. Gillis (Killisu), "Sŏnggyŏng Kwa Chinhwasŏl (The Bible and Evolutionism)," Sijo (January 1933): 13-6. 
an-language publications, possibly because of the political chaos and the Korean War (1950-1953). It was only in the 1970s when creationist literature resurfaced, but Koreans started their formal movement in $1980 .^{9}$

The Korean movement for young-earth creationism is unique in at least three respects. First, it was an endeavor motivated by technical professionals, including scientists, engineers, and physicians. While American creationists coined the term "creation science" as a legal strategy for textbook revision, Korean creationists literally understood the term without knowing anything about its historical context. Indeed, Korean creationists seriously believed that creationism was a science, to which only scholars with adequate scientific credentials could contribute. Hence, the KACR offered its regular membership only to applicants with a master's degree or higher in science, technology, or medicine. ${ }^{10}$ Second, intelligent design creationism (IDC) - a new version of the creationist creed after the 1980s which sought the evidence of God's design in living organisms without saying much about the length of the earth's history-was barely relevant in Korea. Although Lee Seung-Yop (Yi Sŭngyŏp), a mechanical engineer, founded the Korean Research Association for Intelligent Design in 2004, his stance remained marginal among Korean creationists. But this marginal status of IDC in Korea is curious, considering the fact that IDC emerged in America due to young-earth creationists' failure in textbook revision even with the term "creation science."11 Korean creation-

9 For example, see Han Haksu, Kidokkyo Wa Kwahak (Christianity and Science) (Seoul: Yŏngŭmsa, 1973).

10 Kim Young-Gil, “Ch'angjo Kwahak Sayŏk Yisip Nyŏn Ǔl Tolapomyŏ (Looking Back on the Ministry of Creation Science for Twenty Years)," in Han'guk Ch'angjo Kwahakhoe Isip Nyŏn Sa, 59. This rule was abolished during Song Mansuk's tenure as KACR president in the late 1990s. However, most Korean creationists maintained their belief in the significance of science, which I will discuss further in a different publication.

11 As American fundamentalists failed to introduce their "scientific creationism" in public school textbooks, they decided not to mention God or the Bible altogether in their campaign to teach creationism. Their new argument was that the "irreducible 
ists similarly failed in textbook revision, but IDC was not proposed as the most competitive alternative. In any case, the KACR consequently became the Asian center of the most problematic form of creationism that did not even acknowledge the geological time scale, which some, if not all, advocates of IDC accepted. Third, this problematic creed was surprisingly successful despite the fact that Korea had no indigenous tradition of monotheistic religions. In a 2012 survey, about 32 percent of Koreans found creationism was more convincing than evolutionism. ${ }^{12}$ In contrast, other countries with a comparable creationist percentage in their population, such as Greece and Turkey, had their own longstanding monotheistic traditions. ${ }^{13}$ In this sense, Ronald Numbers has called Korea "the creationist capital of the world, in density if not in influence." 14

Of course, some Koreans found this situation shameful. In effect, a number of renowned scientists have criticized the KACR and its members' activities since its founding in 1981. In that year, Ha Dubong (Ha Tubong), a biologist at Seoul National University, argued that "it is a serious illusion to regard creation as a scientific fact." ${ }^{15}$ Lee Byung-Hoon (Yi Pyŏnghun), another renowned biologist at Chonbuk National University, claimed that "so-called creation scientists" were just reiterating their

complexity" of living organisms displayed the evidence of intelligent designer's brilliant craft, although they could not say who the designer was. See Frank S. Ravitch, Marketing Intelligent Design: Law and the Creationist Agenda (Cambridge: Cambridge University Press, 2011).

12 Korea Gallup, Ch'angjoron Kwa Chinhwarone Taehan Yŏron Chosa (A Survey on Creationism and Evolutionism) (Seoul: Korea Gallup, 2012).

13 Park and Cho, "Science, State, and Spirituality," 36-7; Blancke, Hjermitslev, and Kjærgaard, Creationism in Europe, 7-8. The percentage of creationists in Turkey is higher than Korea's, but the two countries cannot be directly compared, because most Turkish creationists do not believe in the young earth theory.

14 Numbers, The Creationists, 418.

15 Kang Sin'gu, “Saengmyŏng: Chinhwa Ŭi Sanmur Inya Sin Ŭi Ch'angjomul Inya (Life: Product of Evolution or God's Creation?)," Kyunghyang Shinmun (17 February 1981). 
religious arguments without publishing any original research articles. ${ }^{16}$ More recently, Jang Dayk (Chang Taeik), along with Shin Jae-Shik (Sin Chaesik) and Kim Yunseong (Kim Yunsŏng), put forward an even harsher criticism through their book, Religion War (Chonggyo Chŏnjaeng, 2009). ${ }^{17}$ To Jang, Shin, and Kim, creation science was complete nonsense from scientific, philosophical, and theological standpoints: scientifically, it had no supporting empirical evidence; philosophically, it could not be justified from any of the viewpoints proposed by scholars like Thomas Kuhn, Imre Latakos, or Karl Popper; and theologically, it was based on an extremely narrow interpretation of the Bible.

However, I think, these problems of creationism do not mean that it does not deserve scholarly attention. By studying creationism in Korea, we can understand the characteristics of modern religion that somehow becomes even more vigorous, despite many scientists' persistent efforts to "enlighten" the people. ${ }^{18}$ We can also understand the KACR's scientific members as key players in Korean Christianity by studying creationism. There are many academic studies of Koreans' reception and development of Christianity in history, but most of them address only pastors, theologians, and missionaries as religious leaders. In contrast, the history of the KACR demonstrates that scientists and engineers did play leading roles. We can then ask how their technical knowledge was translated into their

16 Lee Byung-Hoon, "Saengmul Ǔn Chinhwa Hanŭn'ga (Do Living Organisms Evolve?)," Ŏllon Kwa Pip'yŏng (December 1989).

17 Shin Jae-Shik, Kim Yunseong, and Jang Dayk, Chonggyo Chŏnjaeng (Religion War) (Seoul: Science Books, 2013).

18 Hee-Joo Park has argued that the television debates between creationists and evolutionists in the United States ironically contributed to spreading creationism further in the 1960s, although most creationists were utterly defeated and humiliated during the debates. The broadcasting of such debates in the mass media, rather than their outcome, was important to audiences who often believed that what they saw were serious scientific controversies among renowned experts. See Hee-Joo Park, "The Creation-Evolution Debate: Carving Creationism in the Public Mind," Public Understanding of Science 10 (April 2001): 173-86. 
religious discourses. Of course, their discourses were fraught with problems. As Jang and others have articulated, they disseminated their religious creed disguised as science. However, we can still learn a lot through our research on creationism, just as historians of science have long studied astrology, alchemy, and phrenology as important cultural practices with significant social and political implications. ${ }^{19}$ Although these practices are not "sciences" from our contemporary standpoint, our knowledge on their place in history broadens our view of the past.

This special issue in the International Journal of Korean History includes three articles. Song Sang-yong's paper places Korean creationism within a long history of interaction between science and religion in the history of science. As Song has described, science and religion had a complex relationship, subject to varying scholarly interpretations. They were not necessarily antithetical to each other, as they modified themselves depending on shifting circumstances. However, Song argues, Christian fundamentalists in both America and Korea during the twentieth century posed a novel dilemma, because they refused to modify their religious theory in accordance with the latest developments in the evolutionary sciences. Born as an antiscientific movement supported by ultra-right wing political factions, creationism was thus an illegitimate child of the science-religion relations, which could not be justified by any historical or philosophical point of view.

In contrast, Jang Junoh takes a far more lenient stance toward creationism in his study of Lee Eunil's (Yi Ünil) research on cultured human cells. Lee, the sixth president of the KACR and a medical investigator, was possibly the only Korean creationist who conducted actual creation research. As Jang has described, Lee found in Scripture that Antediluvian humans had enjoyed a much longer duration of life, and there was a dense water canopy in the sky that must have caused a high air pressure in the era before the Genesis Flood. As the flood converted all that sky water into rain, the air pressure considerable dropped thereafter. Simultaneously,

19 Numbers, The Creationists, 14. 
however, the humans' lifespan substantially decreased, according to the Old Testament. From these biblical statements, Lee surmised that the relationship between air pressure and lifespan could be uncovered through cultured cells: cells grown under an elevated air pressure would live longer and suffer fewer malignancies, just like those in Noah's and his ancestors' bodies. But this research begs important questions: To what extent was this a meaningful experimental study? Few scientists outside of the KACR would feel sympathetic to the rationale behind Lee's design of his research, but what could they say about the outcome of this research, which mentioned neither God nor Scripture, and was published in international biomedical journals after peer review? Was Lee disingenuous in concealing his true intent in publishing his papers in these journals? Jang approaches these questions by analyzing Lee's identity as an experimental researcher and Christian fundamentalist. Readers can decide if Jang was right or not.

Jeong Younghoon's paper illustrates another important dimension in Korean creationism by scrutinizing journalistic responses to the 2012 textbook revision debate. Analyzing eight Korean newspapers' reporting of this debate provoked by the Society of Textbook Revision (STR, Kyogwasŏ Chinhwaron Kaejŏng Ch'ujinhoe) - a young-earth creationist organization affiliated closely with the KACR_-Jeong has concluded that the debate was not considered a cultural and political problem that deserved extensive media coverage. Rather, it was seen as a matter of "dry scientific facts" that would hardly attract readers' attention. Hence, few journalists extensively dealt with the debate, before Soo Bin Park's $\mathrm{Na}$ ture article reported STR's near-success as a significant threat to the Korean science education. ${ }^{20}$ Afterwards, many Korean journalists suddenly began to report on this issue. However, there was still no evidence that Koreans had a different view of the debate. Why, then, did they think that the creation-evolution debate was just a matter of "dry" facts? In the

20 Soo Bin Park, "South Korea Surrenders to Creationist Demands," Nature 486 (June 2012): 14. 
United States and other countries, the debate was often triggered in distressing political situations and was perceived as a troublesome social phenomenon intertwined with different groups' distinct cultural and economic interests. ${ }^{21}$ In a sense, Korea was no exception, because creation science was introduced into the country by the right-wing anticommunist pastor Kim Joon Gon in 1980. ${ }^{22}$ Hence, Jeong's paper leads us to delve further into the place of creationism in Korean society. Why was it a matter of "dry" facts to Koreans in the early twenty-first century?

To some readers, the latter two papers featured in this special volume-Jang's and Jeong's - may not look historical, because they are dealing with almost contemporary issues. However, I think that their topics have already become a part of the past. Addressing people and events in the early twenty-first century, the two articles will be useful and relevant to later historians who are going to revisit the problems some time later. Indeed, Korean creationism has not attracted adequate scholarly attention, despite its persistent expansion since 1980. I hope that this special volume can fill this gap, although the current contributions are not extensive enough to cover the entirety of creationism in Korea.

\section{References}

1. Blancke, Stefaan and Hans Henrik Hjermitslev and Peter C. Kjærgaard, eds. Creationism in Europe. Baltimore: Johns Hopkins University Press, 2014.

2. Choi, Taeyon. "Sin Kwa Chinhwa: Han'guk Ǔi Yusin Chinhwaron Nonjaeng (God and Evolution: Korean Debates on Theistic Evolution)." Sinanggwa Hangmun 9 (June 2004): 267-93.

3. Coleman, Simon and Leslie Carlin, eds. Cultures of Creationism:

21 See the chapters in Coleman and Carlin, Cultures of Creationism; Blancke, Hjermitslev, and Kjærgaard, Creationism in Europe; Larson, Summer for the Gods.

22 Park and Cho, "Science, State, and Spirituality," pp. 46-54. 
Anti-Evolutionism in English-Speaking Countries. Aldershot: Ashgate, 2004.

4. Larson, Edward J. Summer for the Gods: The Scopes Trial and America's Continuing Debate over Science and Religion. New York: Basic Books, 2006.

5. Numbers, Ronald L. The Creationists: From Scientific Creationism to Intelligent Design. Cambridge: Harvard University Press, 2006.

6. Park, Hee-Joo. "The Creation-Evolution Debate: Carving Creationism in the Public Mind." Public Understanding of Science 10 (April 2001): 173-86.

7. Park, Hyung Wook and Kyuhoon Cho. "Science, State, and Spirituality: Stories of Four Creationists in South Korea." History of Science 56 (March 2018): 35-71.

8. Peter L. Berger, ed. The Desecularization of the World: Resurgent Religion and World Politics. Grand Rapids: William B. Eerdmans, 1999.

9. Ravitch, Frank S. Marketing Intelligent Design: Law and the Creationist Agenda. Cambridge: Cambridge University Press, 2011. 
